\title{
THE INFLUENCE OF THE ,KOMISARZ ALEX“ TV SERIES ON THE DEVELOPMENT OF LÓDŹ (POLAND) IN THE EYES OF CITY INHABITANTS
}

\author{
Waldemar CUDNY
}

\begin{abstract}
The issues of creative and cultural industries and their role in city branding and development are explored in this paper. Activities enhancing city placement and city branding via a TV series are subject to enquiry. As a result, the city becomes a film-friendly destination, attracting people and firms from the film industry. Besides, the city is perceived more favourably, standing out from the competition and possibly attracting tourists and potential investors and immigrants. Such a policy has been introduced in Eódz, a large Polish post-socialist and post-industrial city. With the city authority's support, the town has become the location of a popular TV crime series, entitled "Komisarz Alex" ("Inspector Alex"). The main aim of the research was to investigate how Eódź inhabitants perceive the series and what influence they think the film-making would have on the city. The evaluation of the perception of the series is based on structured interviews, and is generally very positive.
\end{abstract}

\section{Shrnutí}

\section{Vliv televizního seriálu "Komisař Alex" na rozvoj Lodže (Polsko) očima jeho obyvatel}

Článek prezentuje problematiku kreativního a kulturního prümyslu a jejich roli pro marketingovou značku a rozvoj města. Autor uvádí aktivity, zvyšujici městské renomé a povědomí o městě díky televiznímu seriálu. Město se díky filmu stává atraktivní destinací a pritahuje lidi a firmy z filmového průmyslu. Mimo to je město vnímáno $v$ konkurenčním prostředí př́znivěji a může být atraktivní pro turisty, potenciální investory i imigranty. Taková strategie byla prijiata v Lodži, velkém polském post-socialistickém a post-industriálním městě. S podporou městských úradů se město stalo místem populárních kriminálních seriálů nazvaných "Komisař Alex" ("Inspector Alex”). Hlavním cílem autora bylo zjistit, jak obyvatelé Lodže vnímají seriál a jeho možný vliv na rozvoj města. Hodnocení vycházelo ze strukturovaných rozhovorů.

Key words: TV series, culture industries, city placement, Łódź, Poland

\section{Introduction}

This paper presents the development opportunities and creation of a positive image for the post-socialist and post-industrial city of Łódź, by locating it in a popular TV crime series entitled Komisarz Alex (Inspector Alex). The research used a questionnaire survey conducted among the inhabitants of Łódź, regarding the perception of the series and its impact on the promotion and further development of the city. The main aim of this article is to answer the following questions: What do Łódź inhabitants think of the series? What is the way in which Łódź is presented? How can the fact that the series is made in the city influence its socioeconomic development? Do the inhabitants think that the support, which the series received from the city authorities, was justified?

In recent years, Łódź has been shrinking due to the decline of its industrial economic base. Poor development prospects made many inhabitants move abroad or to other cities in Poland. As a result, negative stereotypes of the city, perceived as impoverished, neglected, uninteresting and dangerous, became deeply rooted in people's minds (see Cudny, 2012; Young, Kaczmarek, 1999, 2008). The negative image of Łódź could even be found in the British media, where in 2013 it was criticized in The Sun magazine. In a report concerning the development of Polish cities, prepared by the PWC Polska consulting company (formerly PriceWaterhouseCoopers - http://www.pwc.pl/pl/wielkiemiasta-lski/lodz.jhtml), improving the city's image was considered to be one of the main challenges. The problem was also voiced in public debates. Therefore, in recent years, a lot has been done not only with the restructuring of Łódź in mind, but also to change the unfavourable image of the city.

Given these recent trends, this research examines how the role of the Inspector Alex TV series in the development of the city is perceived by Łódź inhabitants. The scarceness of studies presenting inhabitants' opinions regarding prodevelopment activities carried out in their cities was pointed out by Olsson and Berglund (2009, p. 127). However, such analyses of the perception of the cultural economy and creative industries have been conducted before, as in studies of the role of events in the development of regions, as perceived by their inhabitants. A similar approach was taken here - to evaluate the influence of television productions on the development of Łódź - in the eyes of its inhabitants.

\section{Research themes in the literature}

The socio-economic development of regions (including urban areas), as well as the transformation of postcommunist countries, are key issues in modern sciences such as geography (Jančák et al., 2010; Hampl, 2007; Rusnák, Korec, 2013). Recently, some urban centres have climbed the hierarchy of cities (see Lentz 1997; Connell, 2000), while others have lost their economic status and a large number of their inhabitants (depopulation, the phenomenon of 'shrinking cities') (see Vaishar, 2002; Liszewski, 2009; 
Cudny, 2012; Rumpel, Slach, 2012; Buček, Bleha, 2013). Such changes have been analysed in Western Europe or the United States for several decades, due to the decline of traditional economies based on mass industrial production, the emergence of post-Fordism and, consequently, the formation of a new type of city. Economically, it is based on modern industries, services, and also culture-related ones, as well as on a social group - the creative class (Amin, 1994).

According to Florida (2002b), the creative class is a social group which is to become a city's driving force in the postFordist era. The question is why creative people tend to be attracted to particular cities. Florida (2003) believes that this is caused by three 'T's: technology (innovation and high technology concentration), talent (concentration of people with university degrees), and tolerance (inclusiveness and diversity of all ethnicities, races and walks of life). Florida also noticed the correlation between the level of urban modernity and the presence of artists and artistic activity. A "bohemian" atmosphere attracts other representatives of the creative class, who in turn contribute to the economic development of cities and regions (Florida, 2002a).

The creative class theory has permeated local and regional planning strategies in most parts of the western world, but it has been often criticised (Rausch, Negrey, 2006; Asheim, Hansen, 2009; Storper, Scott, 2009) for adopting research schemes created in the Anglo-American world in other regions, where they sometimes are not applicable (Gibson, Klocker, 2004; see also Martin-Brelot et al., 2010; Hansen, Niedomysl, 2009). The significance of the creative class for the economic development of cities is also questioned (Krätke, 2010), as well as the methodological assumptions of the theory and insufficient empirical studies (Peck, 2005; Hansen, Niedomysl, 2009). Despite these reservations, many cities that are currently in crisis and searching for new opportunities, are trying to introduce development strategies based on attracting the creative class to their region.

Moreover, such cities often choose the development of culture and related services as a strategic branch of economy (Pratt, 2008). That is why it is possible to create the "bohemian" atmosphere mentioned above, which is crucial for attracting the creative class, but also for generating additional jobs and income.

Activities related to culture, entertainment and media belong to the category of creative or cultural industries. Both of these terms have very similar meanings (Pratt, 2008). Cultural industries deal primarily with symbolic goods, whose primary economic value derives from their cultural value. There are the 'typical' cultural industries (broadcast media, film, publishing, recorded music, design, architecture, new media), and the 'traditional arts' (visual art, crafts, theatre, musical theatre, concerts and performance, literature, museums and galleries). Cultural industries generate certain values, like income, taxes and jobs, and form the cultural economy (O'Connor, 1999; Scott, 2010). Activities related to cultural industries are often seen as a possible way to restructure post-industrial cities and often become pillars of a new economic base ${ }^{1}$. Such processes are called culture-led regeneration strategies (Binns, 2005). Film production is a part of cultural economy, as it may well be included in the group of creative and cultural industries (Scott, 2002; Gibson, Kong, 2005). TV series production may be approached in a similar way (Evans, 2009), and film and television artists should also be treated as members of the creative class.

In the last decades of the $20^{\text {th }}$ century, the media started to be treated as a means of promoting the geographical spaces of regions, including cities. The important role of the media in shaping images of space was noted by geographers, who changed the geographical research paradigm concerning cultural geography. It evolved from a descriptive approach to the new cultural geography (see Cosgrove and Jackson, 1987; Hermanova et al., 2009). Researchers representing the latter trend are presently dealing with media issues, including the role of films and TV series in creating the image of regions and their development (Beaton, 1983; Scott, 2002; Arreola, 2005; Lukinbeal and Zimmermann, 2006; Reijnders, 2009, 2010).

This was reflected as well in the development of media geography - a cultural geography sub-discipline (Zimmermann, 2007; Döring and Thielmann, 2009). The media take part in the geographical study of the human environment. Therefore, they are an object of geographers' interest (Burgess, 1990). The influence of media on the awareness and perception of geographical space is not a new fact (Zimmerman, 2007): along with the development of electronic media, including film and television, their role in shaping the perception of space was growing. Modern media are extremely important from a geographical point of view, because they have a strong effect on people's psyche and their perceptions of geographical space (see Escher, Zimmermann, 2001; Aitken, Craine, 2006; Lukinbeal, Zimmermann, 2006). Modern media, such as the Internet, video animations, Google Maps, Facebook, Flickr (see Döring, Thielmann, 2009), have become increasingly influential as well.

Many regions and cities exert a lot of effort in creating a unique and positive brand in order to achieve economic and tourist growth through 'place branding'. This is a process of creating an image of a given space, e.g. of a city, taking advantage of human perceptual processes. People usually evaluate places on the basis of simple clichés, which they associate with a given site. Therefore, city authorities prepare promotional campaigns, which evoke positive associations. They choose a typical element and try to popularize it so that it becomes the city's cliché, with which it will be associated (Anholt, 2007).

Examples of complex promotional campaigns, which aim to create a positive brand, can be found in many European cities. Amsterdam authorities, for example, noticed the problem of the city being commonly associated with drugs and sex, so they embarked on a mission to change this image and create a new brand. Their strategy included developing cultural events and hospitality, a new press policy, key projects, and inventing new city slogans and logos (Kavaratzis, 2008).

After the fall of communism in Hungary, Budapest authorities launched an innovative marketing campaign. The promotion of the city, presented as a centre of business, creativity, culture and entertainment, was to attract western tourists. Together with other European cities, Budapest was promoted outside Europe. Private investors and EU funds helped to develop the infrastructure (Kavaratzis, 2008).

\footnotetext{
${ }^{1}$ Cultural economy is used in restructuring large cities, but recently it has become a frequent element of restructuring and development plans for small towns (Lorentzen, Van Heur, 2012), regions (Gibson Connell, 2012; Lindeborg, Lindkvist, 2013), as well as rural areas (Drda-Kühn, Wiegand, 2010; Gibson, Connell, 2011).
} 
Films and TV productions often become a part of such procedures, known as product placement. Certain products are shown in films and TV series to increase their sales. Using film and TV productions for such purposes is also possible due to the strong impact, which they have on human perception $^{2}$ (Lukinbeal, Zimmermann, 2006). A positive brand of a city can also be created by showing it in films and TV productions (Morgan et al., 2004, p. 208). If a city is presented in a popular film or TV production in a positive way (as clean, safe, fascinating, connected with culture, entertainment, modern industry), it is extremely significant for its branding.

Tourists often choose the destination of their trip on the basis of what they have seen in the movies (Bolan, Williams, 2008; Mathews, 2010). For instance, in the Italian region of Apulia it was calculated that 1 Euro invested in film production brings 6 Euros of profit, mainly from tourism. In Poland, such calculations were made for Krakow, where 1 zloty (PLN) invested in film production brings on average 1.5 zlotys of profit from tourism (Gorczyca, 2013). Note that over the year 2013, 1 PLN = ca. 0.24 EUR. Film tourism involves travelling in order to visit places and buildings where films were made, attend film festivals, visit film-related institutions (e.g. museums, film studios), or take part in a film production (e.g. as an extra) (Zmyślony, 2001; Hudson, 2011). Apart from cinema movies, film tourism also refers to TV productions, such as crime drama series (Reijnders, 2009, 2010). There are numerous places all over the world, where famous films and TV series were made (Fig. 1). Many of them attract tourists, who travel there individually or take part in organized trips (see: http://www. movie-locations.com).
Apart from tourists, inhabitants, immigrants and investors are also intended recipients of urban marketing campaigns (Philo, Kearns, 1993; Short et al., 1993, Gómez, 1998). The inhabitants wish to live in an appropriate place, work and relax, companies look for suitable places to do business and recruit employees. Therefore, media-based marketing strategies create the image of a geographically-defined place also with the inhabitants and investors in mind. Activities aimed at improving the inhabitants' perception of the city, integrating them and preventing them from leaving the city, are called 'internal marketing' (Hospers, 2004).

The 1990s were marked by substantial transformations of cities in countries where communism had been abolished. "The post-socialist cities are at the transition stage. They are characterized by dynamic processes of change rather than by static patterns. The urban environment formed under the previous system is being adjusted and remodelled to match the new conditions of the political, economic and cultural transition towards the capitalist society. Many features of a socialist city suddenly stood in opposition to the capitalist principles, which led to the restructuring of the existing urban areas. With time, new capitalist urban developments are having more and more influence on the general urban organization. Some pre-socialist patterns are re-emerging, some areas from the socialist times are being transformed, and new post-socialist urban landscapes are being created" (Sýkora, 2009 cited in Cudny, 2012, p. 7; see also Matlovič et al., 2001; Sýkora, Bouzarovski, 2011).

Transformations in the post-socialist cities are similar to those observed earlier in the West, moving from Fordism to post-Fordism. Thus, strategies which proved effective in

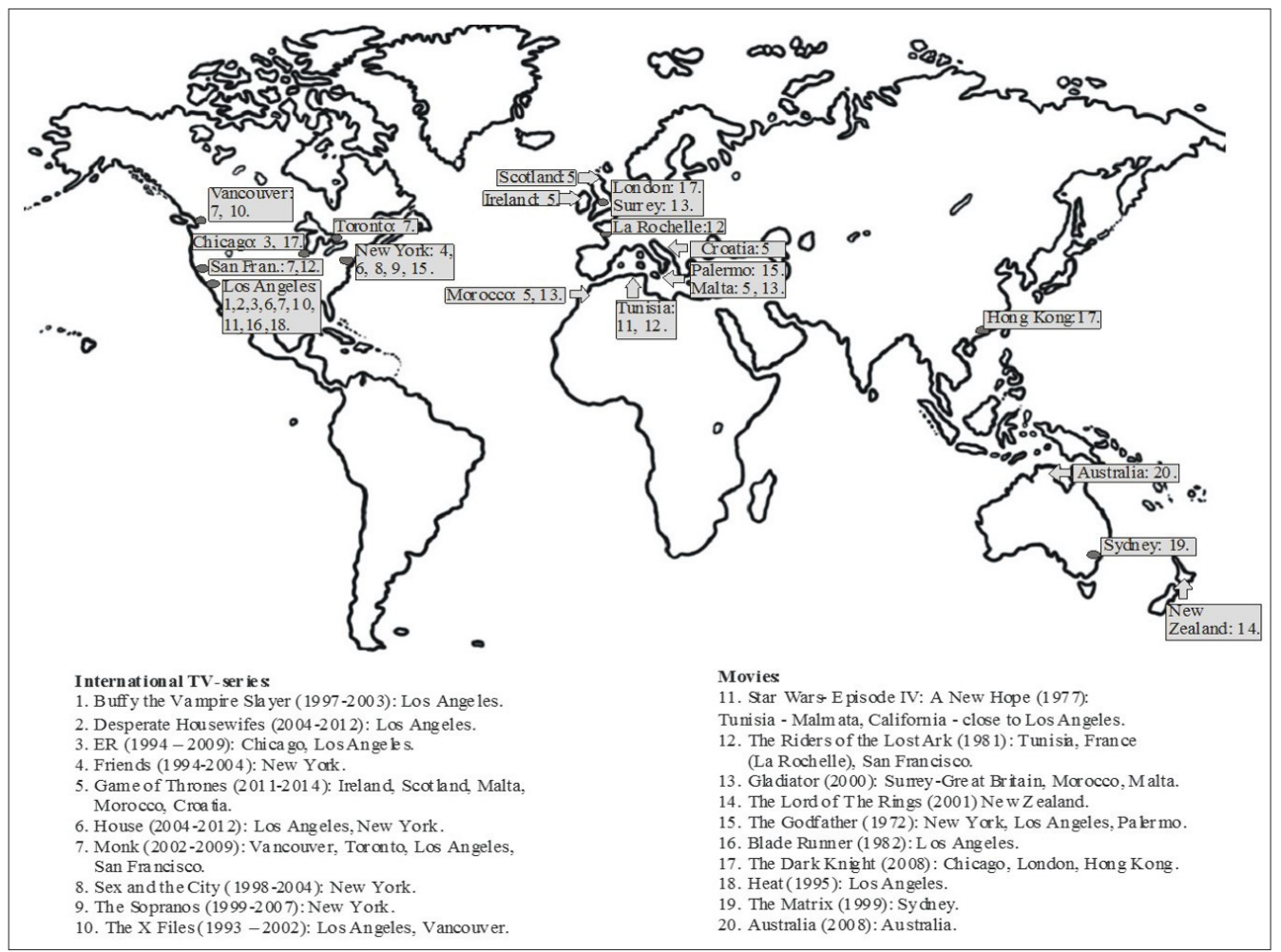

Fig. 1: Location of international TV series and well-known movies

Source: Author's compilation based on http://www.imdb.com/; http://www.wikipedia.org/; http://www.movie-locations.com/

\footnotetext{
${ }^{2}$ Perception is very important for the understanding, interpretation and assessment of geographical space. Perception means 'seeing' phenomena, but this seeing is not completely objective. The process of perception is influenced by a number of factors, such as experience, culture, current attitude or external stimuli (Siwek, 2011). All these elements can be modified by the media, including film and TV productions.
} 
western cities can be used in the restructuring of post-socialist cities (Ondoš, Korec, 2006, p. 52). Some of these strategies are to attract the creative class and creative industries to the city. Culture is being promoted by developing festivals and building cultural facilities. In some marketing campaigns, film, television productions and the Internet are used.

\section{Description of the study area, the "Komisarz Alex" series, research methodology and socio-demographic characteristics of survey respondents}

Łódź is an example of a Polish post-socialist city which experienced rapid socio-economic transformation after 1989. The city developed in the $19^{\text {th }}$ century as a large textile industry centre exporting its goods to the Russian market. In the socialist era in Poland (1945-1989), this traditional economic structure based on the textile industry was preserved and strengthened, but other industries and services were underdeveloped. After introducing a free market in 1989, the out-dated structure of Łódź industry became a burden to the city. Most state textile factories went bankrupt and mass structural unemployment appeared (Liszewski, 2009).

The situation improved slightly when private entrepreneurship started to develop, foreign investors entered the market and the city authorities supported restructuring. At present, Łódź is a large city, showing typical post-Fordist features. Most inhabitants are employed in services, while industry has been partly restructured by introducing modern branches. Powerful investors in the computer and home appliances industries have been attracted to the city. It can boast numerous universities, design and fashion centres, and a rapidly developing cultural and entertainment function, including festivals. It is still difficult to find wellpaid jobs, however, and young people are moving abroad or to other Polish cities. The most serious social problems are depopulation and population aging, which in the long run may cause economic breakdown (Cudny, 2012).

Even in communist times there were cultural institutions based in Łódź which performed important roles. It was also a good time for festivals and avant-garde art events to develop.

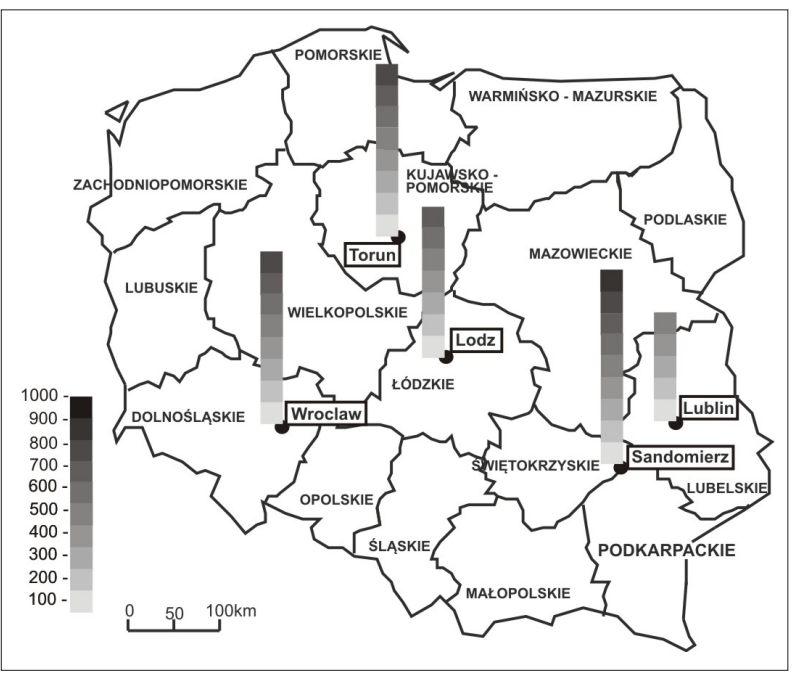

Fig. 2: Cities in which well-known Polish TV series are set: the number of media appearances

Source: Author's compilation based on http://www.pressservice.com.pl/
Moreover, after World War II, the city was the largest centre of film and television production. After 1989, the cultural function collapsed, but later it started to revive (see Cudny, Rouba, 2012).

In recent years, the city authorities have been searching for new investors, promoting cultural development, as well as supporting the making of films and TV series in Łódź. In the "Łódź Brand" strategy for 2010-2016, the development of the creative sector has become the city authorities' priority. The strategy is based on four pillars: culture, economy, education and tourism, and sport. The new promotion slogan adopted for the city is "Creative Łódź". The authorities started to sponsor activities such as design or fairs and organization of festivals. Events receiving a lot of support include the Design Festival (presenting world achievements in industrial design) and the Eódź Fashion Week (the only Fashion Week in Poland). The city collaborates with Łódź high technology industry companies (e.g. Dell) and universities to create a cluster of new technologies. Film production, based on the already-existing institutions and on the activities attracting new specialists and investors, is also strongly supported (http://www.kreatywna.lodz.pl/).

As mentioned above, Łódź is a city which in socialist times already had a well-developed film and TV production sector, despite its predominantly industrial character (see Cudny, Stanik, 2013). It is now one of the most popular Polish tourist destinations as regards film tourism (Stefanik, Kamel, 2011). After World War II, Łódź became the largest centre of film and TV production, with a famous film school established there. Famous Polish TV series and films were made there in those times. Recent years have brought the renaissance of TV series in Poland and Łódź has become the location of two new crime drama series (Paradoks (The Paradox) and Komisarz Alex).

Research on the influence of these TV series on the cities' presence in the media was conducted in 2013 by the Press Service Agency. The city which benefitted most from being promoted in a TV series was Sandomierz, featured in Ojciec Mateusz (Father Matthew) - it was mentioned in the media about 900 times. The series entitled Lekarze (Doctors), shot in Torun, and Pierwsza Miłość (First Love), made in Wrocław, were both mentioned over 800 times. Łódź was mentioned 650 times in connection with Komisarz Alex. Lublin, famous for another TV series shown on the national TV channel - Wszystko Przed Nami (The Bright Future Ahead) appeared in the media 487 times (Gajda Zadworna, 2013; see Fig. 2). As for the Advertising Value Equivalent (i.e. the sum which the city would spend on advertising in order to achieve a comparable number of media appearances), it was 12.9 million zlotys in Wrocław, 10.8 million in Sandomierz, 9.2 million in Torun, and over 6 million in Łódź (http://www.press-service. com.pl/pl/firma/pressroom/informacje-prasowe/art312,w-roliglownej-miasto.html).

Komisarz Alex is a crime drama series, in which the main characters are a Polish police officer and his dog, Alex (Fig. 3). The series is a Polish version of Komisarz Rex (Rex, Cop's Best Friend), an Austrian-Italian detective series. By August 2013, three Polish seasons of Komisarz Alex had been shown, and the fourth season followed at the end of August / beginning September.

All the seasons have been shot in Łódź (http://komisarzalex. tvp.pl/o-serialu/) (Fig. 4). The main male part is played by two young actors - Jakub Wesołowski ( $1^{\text {st }}$ and $2^{\text {nd }}$ season) and Antoni Pawlicki ( $3^{\text {rd }}$ and $4^{\text {th }}$ season). According to the 


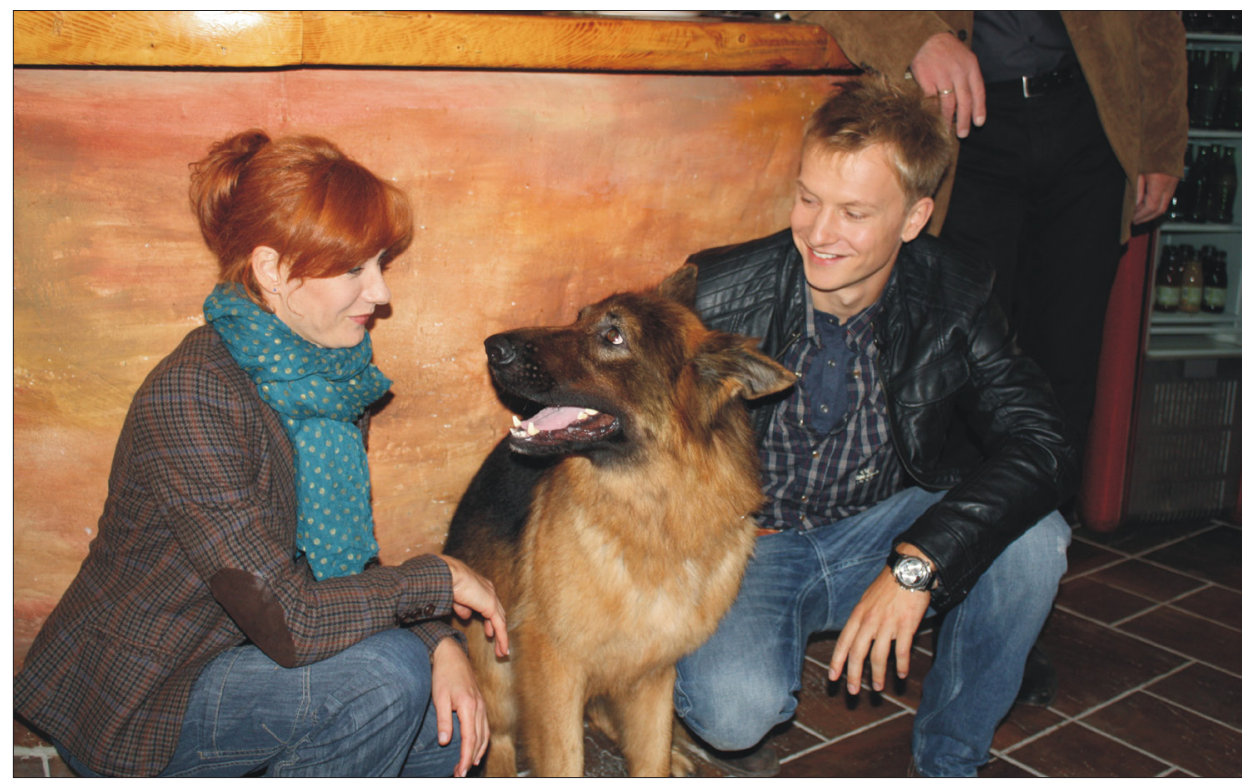

Fig. 3: The main characters of Komisarz Alex (1 ${ }^{\text {st }}$ series): Inspector Marek Bromski (Jakub Wesołowski), Inspector Lucyna Szmidt (Magdalena Walach) and Alex the dog. Source: Eódź Film Commission materials

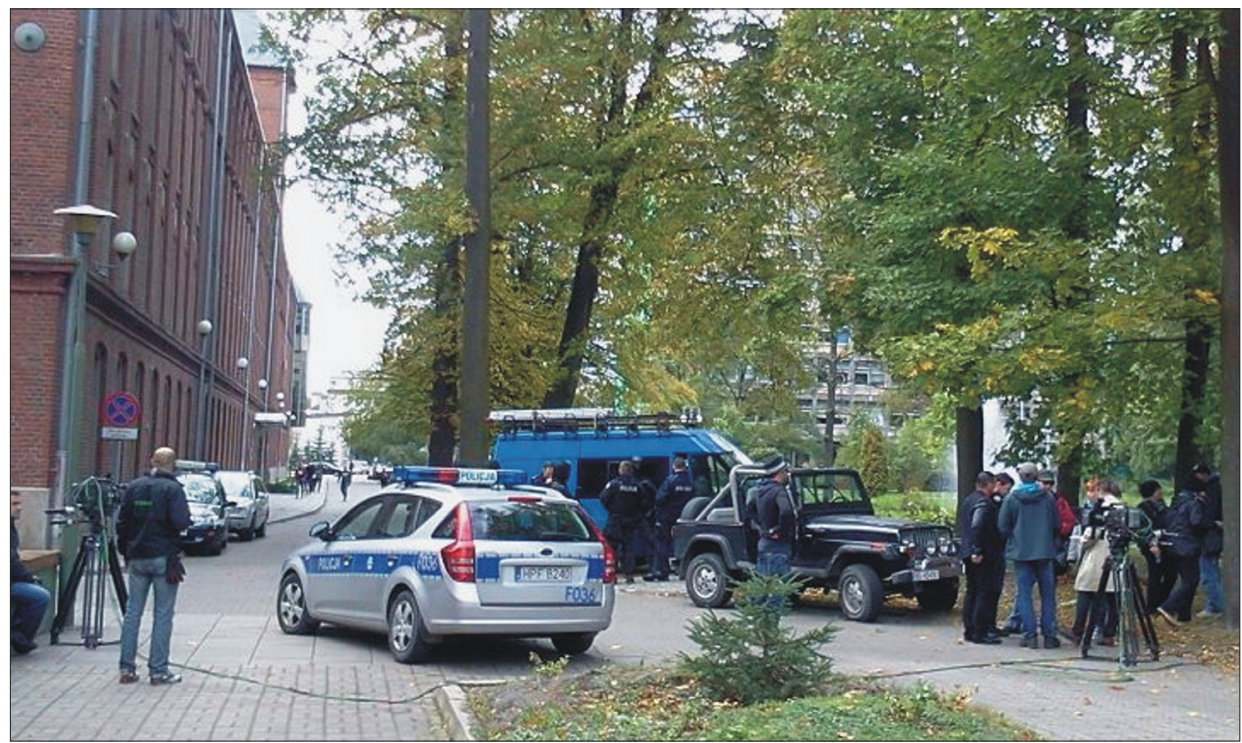

Fig. 4: The making of Komisarz Alex, $4^{\text {th }}$ season. Source: Author

Newsweek magazine (Polish edition), the first episode of Komisarz Alex was watched by over five million viewers. In this way, the story about the adventures of a Łódź policeman helped by a dog beats popular shows presented on other TV channels at the same time: $\mathrm{X}$ factor and Battle of the Voices (Szadkowska, 2012).

The idea to set the series in Łódź was supported by the city authorities from the very beginning. They allocated one million zlotys to the first two seasons and offered organizational assistance through the Łódź Film
Commission, which helped with logistics, mediated with the Police and Municipal Police, as well as with property owners. It also suggested locations ${ }^{3}$, such as the revitalized areas of Piotrkowska Street, Manufaktura, or Wilhelm Scheibler's factory ${ }^{4}$. The city benefits economically from being the location of the series. The producers pay fees for the use of public spaces. The film crew spends money on taxis, accommodation and restaurants.

Making a popular series in Łódź benefits film institutions as well, as film production offers work opportunities to actors

\footnotetext{
${ }^{3}$ Nowadays, in many countries, regions and cities, special institutions are being established, which cooperate with the film industry. They are generally called film commissions, whose task is to attract film producers to given locations (e.g. California Film Commission, The Office of Film, Theatre and Broadcasting in New York, Łódź Film Commission). They have financial means obtained from public funds and private donors, which they may use to subsidize film productions. Moreover, they assist in organizing the very procedures of film and TV series making.

${ }^{4}$ Piotrkowska Street is the main shopping street and promenade in the centre of Łódź. It is the major tourist asset of the city, boasting lavish $19^{\text {th }}$ century architecture in eclectic, secession (art deco) and some historical styles. The Manufaktura Centre is the largest shopping and service centre in Łódź, situated in the former $19^{\text {th }}$ c. revitalized factory built by Israel Poznański. Wilhelm Scheibler's factory complex (Księży Młyn) is the largest post-industrial area in the centre of Łódź. Its valuable, $19^{\text {th }} \mathrm{c}$. factory and residential architecture is currently being revitalized.
} 
and other film-makers associated with the Łódź film school. The film crew cooperates with the already-existing Łódź film production firms (e.g. Opus Film). The Komisarz Alex crew perceive Łódź as a film-friendly destination, thanks to the considerable help and flexibility of the city authorities (Eódź Film Commission's materials).

The promotional role of Komisarz Alex is also very important. The series presents Łódź in a positive way and fights the stereotype of a dirty and neglected post-industrial city by showing mostly its revitalized areas. The main characters are young, creative police officers. They are intelligent, funny, well-dressed and fit. Alex - the dog - is also a very likeable character.

This research project investigated the perception of the series by Łódź inhabitants. This sort of study is used for example in analyzing the influence of events, which generate tourism and additional income, and also used for creating a destination's image (Cudny et al., 2012). Thus, they perform a number of functions similar to those performed by film and TV productions. The research approach used here is similar to the one taken to evaluate the influence of sports events (Fredline, Faulkner, 2001; Waitt, 2003; Lorde et al., 2011; Cudny, Rouba, 2013) or festivals (Cudny et al., 2012) on cities, in the eyes of their inhabitants. Such studies show how the inhabitants assess the promotional and economic role of events or perceive organizational problems related to them (e.g. organization costs, higher prices, etc.), and whether they approve of the authorities' actions supporting the organization of such events.

The aims of this research were similar - to check whether Łódź inhabitants were familiar with this particular TV series, how they evaluated its potential effect and the support it received from the local authorities. Such an analysis also shows whether the inhabitants notice an improvement in the city's image and potential positive socio-economic effects.

The survey was conducted among the inhabitants of Łódź and concerned the Komisarz Alex series and its potential influence on the city. The study used structured interviews, with the person conducting the survey reading questions to respondents from a questionnaire. The respondents' answers are then written down, and if they needed further clarification, it is possible to ask additional questions (Cudny et al., 2011). For this study trained interviewers (The University of Łódź students, supervised by the author) conducted the survey at public places, in the centre of Łódź, mostly in Piotrkowska Street and at the Manufaktura Centre, on 15 and 22 May 2012 in the afternoons.

All respondents were inhabitants of Łódź. The survey instrument included questions concerning four main groups of problems. The respondents were asked if they were familiar with the series, about their opinion of it, and the potential effects of setting the series in Łódź on the city. They were also asked typical socio-demographic items (gender, age, education level, etc.). During the survey, 334 interviews were carried out. In terms of gender, $49.1 \%$ of the respondents were males and $50.9 \%$ were females. Most respondents were 18-25 years of age (43.1\%), and most eager to take part in the survey. They were followed by persons aged 26-35 (24\%), 36-45 (14.4\%) and 46-65 (13.5\%). The smallest group consisted of respondents aged 66 and more years (5\%).

The majority of respondents had completed secondary and university education $-42.8 \%$ and $30.8 \%$, respectively, while $16.5 \%$ had completed vocational, $8.1 \%$ post-secondary and $1.8 \%$ primary education. The survey included working people (62.3\%), school and university students $(20.4 \%)$, old age pensioners $(9.5 \%)$ and some unemployed persons $(7.8 \%)$.

\section{Study results}

The first question tested the respondents' familiarity with Komisarz Alex: "Describe briefly what the Komisarz Alex series is about". Most respondents claimed that it is a crime drama series with a dog playing one of the leading roles (47.6\%), a crime drama series (29.9\%), a Polish version of another series - Komisarz Rex (3.6\%). The respondents' answers show they were familiar with the plot. Some of them even knew what the original series was.

The next question tested the respondents' familiarity with the realities of the series: "Name up to three Eódz locations shown in the series". This was asked in order to check whether the inhabitants could recognize the places shown in Komisarz Alex. This question was important, considering the city authorities' support for the series, which is to promote the city by showing interesting locations. The research aimed to check whether the inhabitants thought that these locations were easily recognizable in the film. Here, each respondent could quote several locations: we received 792 answers. The locations shown in the series were identified correctly. It was usually the Manufaktura Centre (34.8\%), Piotrkowska Street (27.0\%), and the former Scheibler's factory (Księży Młyn, 15.4\%). Another site which was mentioned quite often (7.4\%) was one of the main squares in the city centre - Wolności (Liberty) Square; other answers were more varied and were registered for $15.4 \%$ of cases. The respondents recognized places such as Łódź parks or the Łódź Gallery Shopping Centre. Also here the respondents were well familiar with the film realities. The locations pointed out by them are indeed the sites most often presented in Komisarz Alex. For example, many scenes in different episodes were shot at the Manufaktura Centre and in Piotrkowska Street, while the former Scheibler's factory accommodated the police station (the building of the former factory fire brigade).

The second part of the survey was devoted to the evaluation of the artistic value of the series (the plot, directing and actors' performance). It shows how popular the series is. On a Polish internet portal devoted to films and TV series (http://www. filmweb.pl/), Komisarz Alex was described by 4,257 Internet users as "not bad". It achieved an average of 5.6 points out of 10 (http://www.filmweb.pl/serial/Komisarz+Alex-2012-629466). For comparison, another popular TV crime series made by national television - Ojciec Mateusz - was rated only slightly higher, achieving 6.1 points (http://www.filmweb.pl/serial/ Ojciec+Mateusz-2008-487834).

The next question was "What is the one word you would use to evaluate the series?" Generally, the respondents' opinion regarding the artistic and entertainment value of the series was positive, as $56 \%$ of them rated it as 'very good' or 'good'; $15.8 \%$ rated it as 'average' and $15.9 \%$ expressed a negative opinion. Other answers, which were quite vague, were given by $12.3 \%$ of the respondents (Tab. 1). Although most opinions were positive, the average and negative ratings still make up about $30 \%$, which should encourage the authors of the series to focus more on the artistic side of the production. Increasing expenditure on the series production, as well as devoting more attention to the screenplay and directing, might improve the perception of the series and its locations. 
The following question was "How do you rate (on a scale 1-5) the following elements: screenplay, directing, actors' performance, the dog acting in the series?" The respondents could allocate a number of points to each element: 1 - 'very poor', 2 - 'poor', 3 - 'average', 4 - 'good' and 5 - 'very good'. Based on the responses, mean values for all the mentioned elements were calculated. The actors' performance and the dog's acting were rated the highest. The remaining elements, such as screenplay and directing were also evaluated positively - as average plus (Tab. 2). The responses to this question confirm previous reservations regarding the quality of the screenplay and directing, which might have been of better quality.

The third part of the survey concerned the support provided by the city authorities and its influence on Łódź The first question asked in this part was "Do you think that the city authorities' support (also financial) for locating the series in Łódź was appropriate? Please justify your answer". As much as $68 \%$ of the respondents said that the support was justified, $29.6 \%$ were of the opposite opinion, and $2.4 \%$ did not have any opinion. The most frequent justifications of positive answers included the following: the need to support the development of the city (by locating film and TV productions there), and the fact that the money invested in the series may be returned (e.g. due to increased number of tourists). On the other hand, negative answers were mostly justified by the opinion that the city should not support TV series at all and should use the money for other purposes. Negative opinions might have resulted from the low number of tourist products associated with the series. Its potential is not fully used and the inhabitants' ratings are lower. So far, only a tourist trail has been prepared, taking tourists to places shown in the series. Apart from an Internet website and materials for tourists and tourist guides, there are no other attractions, such as an exhibition related to the film, facilities, e.g. restaurants (places of this kind can be found in Sandomierz, where Ojciec Mateusz is filmed), or promotional events in which the series cast take place. Such steps should be taken at the time when the series is broadcast, in order to take advantage of its popularity in the media.

\begin{tabular}{|l|c|}
\hline \multicolumn{1}{|c|}{ Rating } & \% of answers \\
\hline Very good & 21.0 \\
\hline Good & 35.0 \\
\hline Average & 15.8 \\
\hline Poor & 11.7 \\
\hline Very poor & 4.2 \\
\hline Other & 12.3 \\
\hline Total & $\mathbf{1 0 0 . 0}$ \\
\hline
\end{tabular}

Tab. 1: General rating of the Komisarz Alex TV series by survey respondents. Source: Author's compilation

\begin{tabular}{|l|c|}
\hline \multicolumn{1}{|c|}{ Series element } & Average \\
\hline Screenplay & 3.6 \\
\hline Directing & 3.6 \\
\hline Actors' performance & 3.7 \\
\hline Dog acting in the series & 4.6 \\
\hline
\end{tabular}

Tab. 2: Respondents' rating of the series elements - mean values. Source: Author's compilation
The next question concerned the respondents' opinion about the influence of the series: "Do you think that the Eódz locations shown in the Komisarz Alex series have a positive effect on the perception of the city by the viewers (justify your answer)?" As much as $92.8 \%$ of the respondents said "yes", $5.7 \%$ said "no" and $1.5 \%$ did not have any opinion. Once again, the inhabitants of Łódź appreciated the role of the popular series in creating a positive image of the city. The affirmative answer was usually explained by the fact that the series shows wonderful sites in Łódź. In this way, it promotes Łódź and creates its positive image.

Next, the respondents were asked to refer in more detail to the impact of the series on the city: "What influence do you think the series will have on the image of Eodz, the tourist traffic in the city, the economy of Eódz, the amount of investment in the city?" The aim was to assess to what extent the series attracts specialists and investors, from the film industry too, to Łódź (creative class and cultural industries), as well as to evaluate the potential development of the tourism industry and city promotion. Each respondent could choose one of the following answers: good, slight, no influence, bad, I don't know (Tab. 3). The answers to this question show a very positive opinion about the influence of the series on the image of Łódź and tourist traffic (Tab. 3).

\begin{tabular}{|c|c|c|}
\hline \multirow{29}{*}{$\begin{array}{c}\text { Evaluation } \\
\text { of influence }\end{array}$} & Category & $\%$ \\
\hline & \multicolumn{2}{|c|}{ Łódź image } \\
\hline & Good & 76.3 \\
\hline & Slight & 3.9 \\
\hline & No influence & 9.3 \\
\hline & Bad & 5.1 \\
\hline & I don't know & 5.4 \\
\hline & Total & 100.0 \\
\hline & \multicolumn{2}{|c|}{ Tourism } \\
\hline & Good & 44.9 \\
\hline & Slight & 10.2 \\
\hline & No influence & 24.6 \\
\hline & Bad & 1.8 \\
\hline & I don't know & 18.5 \\
\hline & Total & 100.0 \\
\hline & \multicolumn{2}{|c|}{ City economy } \\
\hline & Good & 19.5 \\
\hline & Slight & 6.0 \\
\hline & No influence & 33.2 \\
\hline & $\mathrm{Bad}$ & 1.5 \\
\hline & I don't know & 39.8 \\
\hline & Total & 100.0 \\
\hline & \multicolumn{2}{|c|}{ Investments } \\
\hline & Good & 18.6 \\
\hline & Slight & 4.8 \\
\hline & No influence & 35.3 \\
\hline & Bad & 5.7 \\
\hline & I don't know & 35.6 \\
\hline & Total & 100.0 \\
\hline
\end{tabular}

Tab. 3: The influence of the series on the city as regards its image, tourism, economy and investment (respondents' answers). Source:Author's compilation 
Such an impact of city placement in a TV series is well described in the literature, as outlined above. It seems that it was also quite well understood by the respondents, who pointed to the positive effect of showing a city in a popular TV series. On the other hand, the impact of such an activity on the city's economy and the growth of investments was less obvious for the respondents. In this case, the answer 'good' appeared in 19.5\% and 18.6\% of responses, respectively (Tab. 3). However, such impact does exist and it is connected with the potential development of the creative field and creative class, due to the growing film sector and the development of a 'bohemian' atmosphere. Besides, the positive perception and the achievable brand of a city associated with film and culture may make the city additionally attractive as a good place to locate new economic investments (not necessarily film-related).

The author believes that such effects are more obvious to urban studies specialists than to the inhabitants, and thus a considerable percentage of answers were 'no influence' and 'I don't know'. Perhaps the responses to this question reflect the relatively small activity connected with the effects of the series. The insufficient number of series-related tourist products may diminish the positive perception of some of its effects. It is advisable to launch an advertising and event campaign, financed by the city. The actors of the series cast could promote the city in commercials and at events as a destination, which is interesting to live in, work in and visit. This kind of policy would help to take advantage of and strengthen the role of the series in creating a positive brand of Łódź

The last question in the survey was of conclusive nature: "Do you think that the next season of Komisarz Alex should be shot in Łódż?" The respondents were asked to justify their answers. The most frequent response was in the affirmative (87.7\%), while $8.4 \%$ gave a negative answer and $3.9 \%$ did not know. The most common justifications for the positive answer were that the series promotes Łódź, the first season was made in Łódź, and that Łódź needs a popular series. The most common justifications of the negative answer were that nobody watches the series, there are things more important, and that the series does not show Łódź in a good light. Here, some respondents pointed to the fact that a crime series is not a good method of promotion, as it shows a given location as a city associated with crime. Such doubts are to a certain extent justified, but the author believes that they are not always confirmed. For instance, despite the criminal theme of Ojciec Mateusz, tourist traffic in Sandomierz greatly increased after it was broadcast. What is more, Komisarz Alex is a series sending a positive message, because it shows crimes that may be committed in any large city. It is not full of violence or bloody scenes and the main characters are positive and optimistic. It is not then an example of a sinister and bloody crime story. The author believes that there is no danger of associating Łódź with excessive criminality due to the series presentation.

\section{Conclusions}

Currently, cultural and entertainment activities, including those related to film and television, are used as a particular kind of culture-based development booster in cities. It is an approach taken as a part of the cultural economy of cities (Scott, 2006, 2010), due to the growing role of cultural industries with respect to economic development, generating jobs and tourism. Another important element of this process is the creative class, the representatives of which are involved in media production (Florida, 2003). Therefore, contemporary cities compete with one another for hosting film and television productions. In post-socialist cities, activities of this type have brought very positive effects, e.g. in Prague, which after the fall of communism has become an important centre of international film-making, thanks to a well-planned policy (Iordanova, 2003).

Moreover, cities compete for resources, which are needed for their future development. These resources include people (inhabitants, immigrants, tourists) and investment capital. Many contemporary cities are undergoing processes of economic stagnation and depopulation (shrinking cities). In such cases, the struggle for these resources is particularly important. Such cities are not only decreasingly attractive for tourists or investors, but they are also losing the resources they have had so far, as a result of the inhabitants' emigration or firms fleeing to more attractive cities with a better image.

Such processes have been observed in the developed economies of western capitalist countries for many decades. More recently, they have appeared in post-socialist countries as well (Lentz, 1997; Korec, 2007; Matlovič et al., 2001; Sýkora, Bouzarovski, 2011). Any transformations taking place in cities of these regions are similar to processes observed in the West earlier, which were connected with the transition from the industrial Fordist to a post-Fordist economy (Ondoš, Korec, 2006).

Łódź is an example of such a post-socialist and postindustrial city with serious socio-economic problems (Liszewski, 2009; Cudny, 2012). It declined socially and economically after the fall of textile industry. At present, Łódź has undergone partial restructuring, as services and modern industry have replaced the traditional textile production. However, the crisis has not finished yet, so the city authorities are trying to introduce a new development strategy. In recent years, the stress has been put on the development of culture, events and creative industries. The Creative Łódź strategy includes supporting the development of film and TV industries, aiming to attract film producers and generate new jobs and income for the city. It is also to support the promotion of Łódź through film and TV productions (place branding).

At present, the role of the media, including film and television, in the creation of an image is extremely important (see Arreola, 2005; Zimmermann, 2007; Döring, Thielmann, 2009; Reijnders, 2009, 2010). The possibility of the development of film-making in the city, which has a long and spectacular tradition, as well as for promotion, had been noticed by the city authorities. Therefore, the production of Komisarz Alex received financial and organizational support from city institutions.

This study investigated how the inhabitants of Łódź evaluated the role of this series and the support it received from the city. The approach chosen has been used many times for studying other cultural economy phenomena, e.g. events (see Fredline and Faulkner, 2001; Waitt, 2003; Lorde et al., 2011; Cudny, Rouba, 2013; Cudny et al., 2012). Studies of this type seek to answer questions such as whether the inhabitants notice the effects of such activities, and whether they approve of the support given to it by the local authorities.

The results of the survey point to a generally positive attitude of the inhabitants of Łódź towards the series. They recognized the majority of the Łódź locations shown in the film and most respondents evaluated the series favourably. As to individual artistic elements, actors appearing in the 
series and the dog were rated the highest, and the screenplay and directing slightly lower. The organizational and financial support from the city authorities was regarded as justified. The respondents stated that making Komisarz Alex in Łódź has a positive influence on the city image and the growth of tourism. The possible effect of the series on the economic development of the city and the growth of investments was rated lower. The author believes that this may result from the fact that effects of this type are less obvious than the promotional or tourist effects. Moreover, too little has been done so far to take advantage of the promotional effect of broadcasting a series made in Łódź. There should be more tourist products, events which would be based on the series and strengthen its promotional effect for tourists, investors or Łódź inhabitants. A promotional campaign should be launched soon, the aim of which would be to intensify and prolong the effects of the series.

\section{References:}

ANHOLT, S. (2007): Competitive identity: The new brand management for nations, cities and regions, Palgrave Macmillan, Basingstoke, 134 pp.

AITKEN, S., CRAINE, J. (2006): Affective Geovisualizations. Directions Magazine, Feb 7 [on line]. Accessible at: URL: http://www.directionsmag.com/articles/guest-editorialaffective-geovisualizations/123211

ARREOLA, D. (2005): Forget the Alamo: The Border as Place in John Sayles' Lone Star. Journal of Cultural Geography, Vol. 23, No. 1, p. 23-42.

ASHEIM, B., HANSEN, H. K. (2009): Knowledge Bases, Talents, and Contexts: On the Usefulness of the Creative Class Approach in Sweden, Economic Geography, Vol. 85, No. 4, p. 425-442.

AMIN, A. (1994) Post-Fordism: Models, Fantasies and Phantoms of Transition, In: Amin, A. [ed.]: Post Fordism: A Reader, Blackwell Publishers Ltd., Oxford, p. 1-39.

BEATON, J. (1983) Why the Movies Chose Hollywood. Journal of Cultural Geography, Vol. 4, No. 1, p. 99-109.

BINNS, L. (2005): Capitalising on Culture: An Evaluation of Culture-led Urban regeneration Policy, Faculty of Built Environment, Dublin, Institute of Technology, section 5. [cit. 05.10.2013], URL: http://arrow.dit.ie/

BUČEK, J., BLEHA, B. (2013): Urban shrinkage as a challenge to local development planning in Slovakia. Moravian Geographical Reports, Vol. 21, No. 1, p. 2-15.

BURGESS, J. (1990): The Production and Consumption of Environmental Meanings in the Mass Media: A Research Agenda for the 1990s, Transactions of the Institute of British Geographers New Series, Vol. 15, No. 2, p. $139-161$.

BOLAN, P., WILLIAMS, L. (2008): The role of image in service promotion: focusing on the influence of film on consumer choice within tourism. International Journal of Consumer Studies, Vol. 32, No. 4, p. 382-390.

COSGROVE D., JACKSON P. (1987): New directions in cultural geography, Area, Vol. 19, No. 2, p. 95-101.

CONNELL, J. (2000): Sydney: The Emergence of a World City. Oxford University Press, Melbourne, 381 pp.

CUDNY, W. (2012): Socio-Economic Changes in Lodz Results of Twenty Years of System Transformation. Geografický časopis, Vol. 64, No. 1, p. 3-27.
CUDNY, W., ROUBA, R. (2012): Lodz - Poland, In: Cudny, W. Michalski, T., Rouba, R. [eds.]: Tourism and the transformation of large cities in the post - communist countries of Central and Eastern Europe, ŁTN, Wydawnictwo Uniwersytetu Łódzkiego, Łódź, p. 34-68.

CUDNY, W., ROUBA, R. (2013): A Large Sports Events in the Eyes of the Host City's Inhabitants: the Example of Wrocław. Polish Sociological Review, No. 4 (184), p. 505-530.

CUDNY, W., STANIK, E. (2013): "Man in Danger" Media Festival in Lodz - the structure and motivations of the festival visitors, Annales UMCS Section B (Geographia, Geologia, Mineralogia et Petrographia), Vol. 68, No. 1, p. 69-90, DOI: 10.2478/v10066-012-0029-0.

CUDNY, W., GOSIK, B., PIECH, M., ROUBA, R. (2011): Praca dyplomowa z turystyki. Podręcznik akademicki. ŁTN, Łódź, 132 pp.

CUDNY W., KOREC P., ROUBA R. (2012): Resident's perception of festivals - a case study of Łódź, Sociológia Slovak Sociological Review, Vol. 44, No. 6, p. 678-703.

DÖRING, J., THIELMANN, T. (2009): Mediengeographie: Für eine Geomedienwissenschaft, In: Döring, J., Thielmann, T. [eds.]: Mediengeographie. Theorie Analyse - Diskussion, p. 9-64, Reihe Medienumbrüche, Transcript Verlag, Bielefeld.

DRDA-KÜHN, K., WIEGAND, D. (2010): From culture to cultural economic power: Rural regional development in small German communities, Creative Industries Journal, Vol. 3, No. 1, p. 89-96.

ESCHER, A., ZIMMERMANN, S. (2001): Geography meets Hollywood - Die Rolle der Landschaft im Spielfilm. Geographische Zeitschrift, Vol. 89, No. 4, p. 227-236.

EVANS, G. (2009): Creative Cities, Creative Spaces and Urban Policy, Urban Studies, Vol. 46, No. 5-6, p. 1003-1040.

FLORIDA, R. (2002a) Bohemia and economic geography, Journal of Economic Geography, Vol. 2, No. 1, pp. 55-71.

FLORIDA, R. (2002b): The rise of the creative class, New York, Basic Books, 404 pp.

FLORIDA, R. (2003): Cities and the creative class, City \& Community, Vol. 2, No. 1, p. 3-19.

FREDLINE, E. FAULKNER, B. (2001): Variations in Residents' Reactions to Major Motorsport Events: Why Residents Perceive the Impacts of Events Differently. Event Management, Vol. 7, No. 2, p. 115-125.

GAJDA ZADWORNA, J. (2013): Nakręcona Polska. Article from the website: http://www.wsieci.pl/nakreconapolska-pnews-157.html, [cit. 02.09.2013].

GIBSON, C., CONNELL, J. [eds.] (2011): Festival places: revitalising rural Australia. Bristol, Tnawanda, Channel View Publications, 298 pp.

GIBSON, C., CONNELL, J. (2012): Music Festivals and Regional Development in Australia. Farnham, Ashgate.

GIBSON, C., KLOCKER, N. (2004): Academic publishing as 'creative' industry, and recent discourses of 'creative economies': some critical reflections, Area, Vol. 36, No. 4, p. $423-434$.

GIBSON, C., KONG, L. (2005): Cultural economy: a critical review, Progress in Human Geography Vol. 29, No. 5, p. 541-561. 
GÓMEZ, M. V. (1998): Reflective images: the case of urban regeneration in Glasgow and Bilbao. International Journal of Urban and Regional Research, Vol. 22, No. 1, p. 106-121.

GORCZYCA, A. (2013): Jak zarobić na „Ojcu Mateuszu” czyli turystyka filmowa. Article from the website: http:/ rzeszow.gazeta.pl/rzeszow/1,34962,14097829,Jak_ zarobic_na_Ojcu_Mateuszu__czyli_turystyka_ filmowa.h̆tml\#ixzz20̄ePN3C2e, [cit. 02.09.2013].

HAMPL, M. (2007): Regionálni diferenciace současného socioekonomického vývoje v České republice. Sociologicky časopis, Vol. 43, No. 5, p. 889-910.

HANSEN, H. K., NIEDOMYSL, T. (2009): Migration of the creative class: Evidence from Sweden, Journal of Economic Geography, Vol. 9, No. 2, p. 191-206.

HEŘMANOVÁ, E., CHROMÝ, P., MARADA, M., KUČEROVÁ, S., KUČERA, Z. (2009): Kulturní regiony a geografie kultury. Kulturní reálie a kultura v regionech Česka, ASPI Wolters Kluwer, Praha. 348 pp.

HOSPERS, G. J. (2004): Place marketing in Europe: The branding of the Oresund region. Intereconomics, Vol. 39, No. 5, p. 271-279.

HUDSON, S. (2011): Working together to leverage film tourism: collaboration between the film and tourism industries. Worldwide Hospitality and Tourism Themes, Vol. 3, No. 2, p. 165-172.

IORDANOVA, D. (2003) Cinema of the other Europe, Wallflower Press, London, 208 pp.

JANČÁK, V., CHROMÝ P., MARADA M., HAVLÍČEK T., VONDRÁČKOVÁ P. (2010): Sociální kapitál jako faktor rozvoje periferních oblastí: analýza vybraných složek sociálního kapitálu v typově odlišných periferiích Česka. Geografie,Vol. 115, No. 2, p. 207-222.

KAVARATZIS, M. (2008): From City Marketing to City Branding. An Interdisciplinary Analysis with Reference to Amsterdam, Budapest and Athens, Doctoral Thesis, University of Groningen, the Netherlands. 203 pp. [online]. Accessible at: URL: http://dissertations.ub.rug. $\mathrm{nl} /$ faculties/rw/2008/m.kavaratzis/

KOREC, P. (2007): Vplyv post-industriálneho štádia vývoja spločnosti a globalizácie na regionálny vývoj Slovenska. Geographia Cassoviensis, Vol. I, p. 75-80.

KRÄTKE, S. (2010): Creative Cities and the Rise of the Dealer Class: A Critique of Richard Florida's Approach to Urban Theory, International Journal of Urban and Regional, Vol. 34, No. 4, p. 835-853.

LUKINBEAL, C., ZIMMERMANN, S. (2006): Film geography: a new subfield, Erdkunde, Vol. 60, No. 4, p. 315-325.

LENTZ, S. (1997): Cityentwicklung in Moskau - zwischen Transformation und globalisierung. Zeitschrift für Wirtschaftsgeographie, No. 23, pp. 110-122.

LINDEBORG, L., LINDKVIST, L. [eds.] (2013): The Value of Arts and Culture for Regional Development. A Scandinavian perspective, Routledge, London, New York, 363 pp.

LISZEWSKI, S. [ed.] (2009): Łódź monografia miasta. ŁTN, Łódź, 501 pp.

LORDE, T., GREEIDGE, D., DEVONISH, D. (2011): Local Residents' Perceptions of the Impacts of the ICC Cricket World Cup 2007 on Barbados: Comparison of Pre and Post games'. Tourism Management, Vol. 32, p. 349-356.
LORENTZEN, A., VAN HEUR, B. [eds.] (2012): Cultural Political Economy of Small Cities, Routledge, Oxon, New York, $216 \mathrm{pp}$.

MARTIN-BRELOT, H., GROSSETTI, M., ECKERT, D., GRITSAI, O., KOVÁCS, Z. (2010): The spatial mobility of the 'creative class': A European perspective, International Journal of Urban and Regional Research, Vol. 34, No. 4, p. 854-870.

MATCHEWS, V. (2010): Set appeal: film space and urban redevelopment. Social \& Cultural Geography, Vol. 11, No. 2, p. 171-190.

MATLOVIČ, R., IRA, V., SÝKORA, L., SZCZYRBA, Z. (2001): Procesy transformacyjne struktury przestrzennej miast postkomunistycznych (na przykładzie Pragi, Bratysławy, Ołomuńca oraz Preszowa). In: Jażdżewska, I., [ed.]: Miasto postsocjalistyczne - organizacja przestrzeni miejskiej i jej przemiany, Wydawnictwo Uniwersytetu Łódzkiego, Łódź, p. 9-21.

MORGAN, N., PRITCHARD, A., PRIDE, R. [eds.] (2004): Destination branding. Butterworth-Heinemann, Oxford. $314 \mathrm{pp}$.

O'CONNOR, J. (1999): The Definition of "Cultural Industries", Manchester Institute for Popular Culture, Manchester. Accessible at: URL: http://mmu.ac.uk/h-ss/ mipc/iciss/home2.htm, [cit. 05.10.2013].

OLSSON, K., BERGLUND, E. (2009) City marketing: the role of the citizens, In: Nyseth, T., Viken A., Place Reinvention: Northern Perspectives, Ashgate, Farnham, p. $127-144$.

ONDOŠ, S., KOREC P., (2006): Súčasné dimenzie sociálnodemografickej priestorovej štruktúry Bratislavy, Sociológia, Vol. 38, No. 1, p. 49-82.

PECK, J. (2005): Struggling with the creative class. International Journal of Urban and Regional research, Vol. 29, No. 4, p. 740-770.

PHILO, C., KEARNS, G. (1993): Culture, history, capital: a critical introduction to the selling of places, In: Kearns, G., Philo, C. [eds.]: Selling places: the city as cultural capital, past and present, Pergamon Press, Oxford, p. 1-32.

PRATT, A. C. (2008): Creative cities: the cultural industries and the creative class. Geografiska Annaler: Series B. Human Geography, Vol. 90, No. 2, p. 107-117.

RAUSCH, S., NEGREY, C. (2006): Does the Creative Engine Run? A consideration of the effect of creative class on economic strength and growth. Journal of Urban Affairs, Vol. 28, No. 5, p. 473-489.

REIJNDERS, S. (2009): Watching the detectives. Inside the guilty landscapes of Inspector Morse, Baantjer and Wallander. Tijdschrift voor Communicatiewetenschap, Vol. 37, No. 2, p. 118-132.

REIJNDERS, S. (2010): Places of the imagination: An ethnography of the TV detective tour. Cultural Geographies, Vol. 17, No. 1, p. 37-52.

RUMPEL, P., SLACH, O. (2012): Governance of shrinkage of the city of Ostrava. European Science and Art Publishing, Praha. 227 pp.

RUSNÁK, J., KOREC, P. (2013): Alternatívne koncepcie postsocialistickej transformácie. Ekonomický časopis, Vol. 61, No. 4, p. 396-418. 
SCOTT, A. J. (2002): A new map of Hollywood: the production and distribution of American motion pictures. Regional Studies, Vol. 36, No. 9, p. 957-975.

SCOTT, A. J. (2006): Creative cities: conceptual issues and policy questions. Journal of Urban Affairs, Vol. 28, No. 1, p. 1-17.

SCOTT, A. J. (2010): Cultural economy and the creative field of the city. Geografiska Annaler, Series B, Human Geography, Vol. 92, No. 2, p. 115-130.

SHORT, J. R., BENTON, L. M., LUCE, W. B., WALTON, J. (1993): Reconstructing the image of an industrial city. Annals of the Association of American Geographers, Vol. 83, No. 2, p. 207-224.

SIWEK, T. (2011): Percepce geografického prostoru. Česká geografická společnost, Praha, 164 pp.

STEFANIK, M., KAMEL, M. (2011): Kreowanie markowego produktu turystyki kulturowej (na przykładzie potencjalnego produktu pt. Filmowym tropem po Polsce). Turystyka Kulturowa, Vol. 8, p. 4-29. Accessible at: URL: http://turystykakulturowa.org/pdf/2011_08_01.pdf [cit. 02.09.2013].

STORPER, M., SCOTT, A. J. (2009): Rethinking human capital, creativity and urban growth, Journal of Economic Geography, Vol. 9, No. 2, p. 147-167.

SÝKORA, L. (2009): Post - socialist cities, In: Kitchin, R., Thrift, N. [eds.]: International Encyclopedia of Human Geography, Oxford, Elsevier, p. 387-395.

SÝKORA, L., BOUZAROVSKI, S. (2011): Multiple transformations: conceptualising the post-communist urban transition. Urban Studies, Vol. 41, No. 1, p. 43-60.

SZADKOWSKA, E. (2012): Komisarz Alex pies na role. Accessible at URL: http:/filmy.newsweek.pl/komisarzalex--pies-na-role,89644,1,1.html [cit. 03.09.2013].

ZIMMERMANN, S. (2007): Media Geography - always part of the game. Aether - the journal of media geographies, No. 1, p. 59-62.

\section{Author's address:}

Dr. Waldemar CUDNY

Institute of Tourism and Economic Development

University of Lódź - Branch in Tomaszów Mazowiecki, Poland

e-mail: algernon321@gmail.com

Initial submission 2 October 2013, final acceptance 10 February 2014

\section{Please cite this article as:}

CUDNY, W. (2014): The influence of the "Komisarz Alex" TV series on the development of Łódź (Poland) in the eyes of city inhabitants. Moravian Geographical Reports, Vol. 22, No. 1, p. 33-43. DOI: 10.2478/mgr-2014-0004.
ZMYŚLONY, P. (2001): Wpływ sztuki filmowej na rozwój nowych produktów turystycznych w Polsce. Problemy Turystyki, No. 3-4, p. 21-30.

WAITT, G. (2003): Social Impact of Sydney Olympics. Annals of Tourism Research, Vol. 30, No. 1, p. 194-215.

VAISHAR, A. (2002): Population Development in the Ostrava Region: Some Aspects and Current Trends. Moravian Geographical. Reports, Vol. 10, No. 2, p. 28-36.

YOUNG, C., KACZMAREK, S. (1999): Changing the Perception of the Post-Socialist City: Place Promotion and Imagery in Łódź, Poland. The Geographical Journal, Vol. 165, No. 2, p. 183-191.

YOUNG, C., KACZMAREK, S. (2008): The Socialist Past and Postsocialist Urban Identity in Central and Eastern Regional Studies, Vol. 15, No. 1, p. 53-70.

http://www.filmweb.pl/- popular Polish internet portal devoted to film and television productions, [cit. 05.09.2013].

http://komisarzalex.tvp.pl/o-serialu/ - official website of the Komisarz Alex series. [cit. 05.09.2013].

http://www.kreatywna.lodz.pl/ - official website of Citz of Łódź, presenting the new development and branding strategy. [cit. 04.10.2013].

http://www.press-service.com.pl/ - the website of Press Service - a firm analysing the media market [cit. 03.09.2013].

http://www.pwc.pl/- strona internetowa firmy consultingowej PwC Polska, [cit. 06.01.2014].

http://www.movie-locations.com/ - website presenting the best known locations of film and TV productions. [cit. 16.09.2013].

http://www.imdb.com/ - website presenting information from the world of film and television. [cit. 15.09.2013].

http://www.wikipedia.org/ - Internet encyclopedia website. [cit. 20.09.2013]. Europe. The Case of Łódź, Poland. European Urban and 